\title{
A Case with Familial Mediterranean Fever which Responds Well to Adalimumab Treatment
}

\author{
Adalimumab Tedavisine İyi Yanıt Veren Bir Ailesel Akdeniz Ateşi Olgusu
}

Özgür ORTANCIL, Aslan SANLI, Perihan SAPMAZ BULMUŞ, Selda SARIKAYA

Departments of Physical Medicine and Rehabilitation, Medical Faculty of Zonguldak Karaelmas University, Zonguldak, Turkey

\begin{abstract}
Ankylosing spondylitis (AS) may accompany Familial Mediterranean fever (FMF). In this article, we present a 48-year-old male FMF case with accompanying AS who was successfully treated with a tumor necrosis factoralpha (TNF-a) inhibitor (adalimumab). Colchicine and other disease modifying antirheumatic drug (sulfasalazine and leflunomide) treatments had been given before the initiation of the TNF-a inhibitor, but FMF attacks could not be adequately controlled by these treatments. When adalimumab was coadministered with colchicine, the disease activity of AS was improved and the frequency and the severity of the FMF attacks were reduced during the one-year follow-up. We conclude that TNF-a blockers may be a therapeutic option when conventional treatment is ineffective in patients with FMF.
\end{abstract}

Key words: Adalimumab; ankylosing spondylitis; familial Mediterranean fever; tumor necrosis factor.

Familial Mediterranean fever (FMF) is an autosomal recessive disease characterized by recurrent fever, peritonitis, pleuritis, and synovitis attacks. ${ }^{[1]}$ Typical attacks accompanied by fever and serositis may be as long as 1-4 days. ${ }^{[2]}$ The most important complication of FMF is amiloidosis which leads to kidney failure. The disease progression improved after colchicine treatment. ${ }^{[3]}$ In addition to joint involvement in the forms of acute or chronic monoarthritis and oligoarthritis in FMF a rare form of involvement seronegative spondiloarthropathy (SNSA) has been reported. ${ }^{[4-7]}$ Langevitz et al., ${ }^{[5]}$ in their study involving
Ankilozan spondilit (AS) ailesel Akdeniz ateşi (AAA)'ne eşlik edebilir. Bu yazıda eşlik eden AS'si olan ve tümör nekroz faktör alfa (TNF-a) inhibitörü (adalimumab) tedavisiyle başarılı şekilde tedavi edilen 48 yaşında bir erkek AAA olgusu sunuldu. Hastaya TNF-a inhibitörü başlanmadan önce kolşisin ve hastalık modifiye edici ilaç (sulfasalazin ve leflunomid) tedavileri uygulandı fakat bu tedavilerle AAA atakları yeterli derecede kontrol altına alınamadı. Kolşisin tedavisiyle birlikte adalimumab uygulandığında, bir yıllık takip esnasında AS hastalık aktivitesinde düzelme sağlandı ve AAA ataklarının sıklığı ve şiddeti azaldı. Geleneksel tedavilerin etkisiz kaldığı AAA hastalarında TNF-a inhibitörlerinin bir tedavi seçeneği olabileceği düşüncesindeyiz.

Anahtar sözcükler: Adalimumab; ankilozan spondilit; ailesel Akdeniz ateşi; tümör nekroz faktör.

3000 FMF patients, identified 11 patients who met the criteria for SNSA and reported that SNSA might be one of the musculoskeletal involvement forms. The study also indicated that it might develop despite colchicine treatment and require a specific treatment. Knockaert et al ${ }^{[8]}$ have suggested that ankylosing spondylitis (AS) may accompany FMF. There are a few reports of FMF cases that were treated with a tumor necrosis factor alpha (TNF- $\alpha$ ) inhibitor. ${ }^{[4,9-12]}$ In this article, we report on a patient who was followed up after a diagnosis of AS for two years, diagnosed with FMF in our clinic and who responded to adalimumab treatment. 


\section{CASE REPORT}

A 48-year-old male patient who had been followed up in another center with the diagnosis of AS was referred to our clinic with complaints of pain in the lower back, neck, and right hip increasing at rest and decreasing with activity. The locomotor system examination revealed that the cervical and lumbar vertebra motions were limited and painful. The motions of the right hip were painful, and extension and rotation were limited. The Mennel test and Patrick-Faber test were positive on the right side. The lumbar Schober test was $2 \mathrm{~cm}$, and chest expansion was $2 \mathrm{~cm}$. The anterior-posterior sacroiliac joint graph revealed bilateral stage IV sacroiliitis along with concentric narrowing in the joint space of the right hip (Figure 1), and the anterior-posterior lumbosacral graph revealed syndesmophytes (Figure 2). The patient was found to be human leukocyte antigen-B (HLA B27) ${ }^{(-)}$. He had been followed up for seven years at another center with the diagnosis of renal failure associated with nephrolithiasis and had used sulfasalazine and leflunomide for AS. The patient had stopped using sulfasalazine and leflunomide on the recommendation of the nephrology department 1.5 months before attending our clinic. The patient was hospitalized for adjustment of his medical treatment. During follow-up, his temperature was 38-38.5 ${ }^{\circ} \mathrm{C}$, and the patient developed abdominal pain. Detailed history revealed that the patient had been suffering recurrent attacks of fever and abdominal pain once a month for 15 years. At

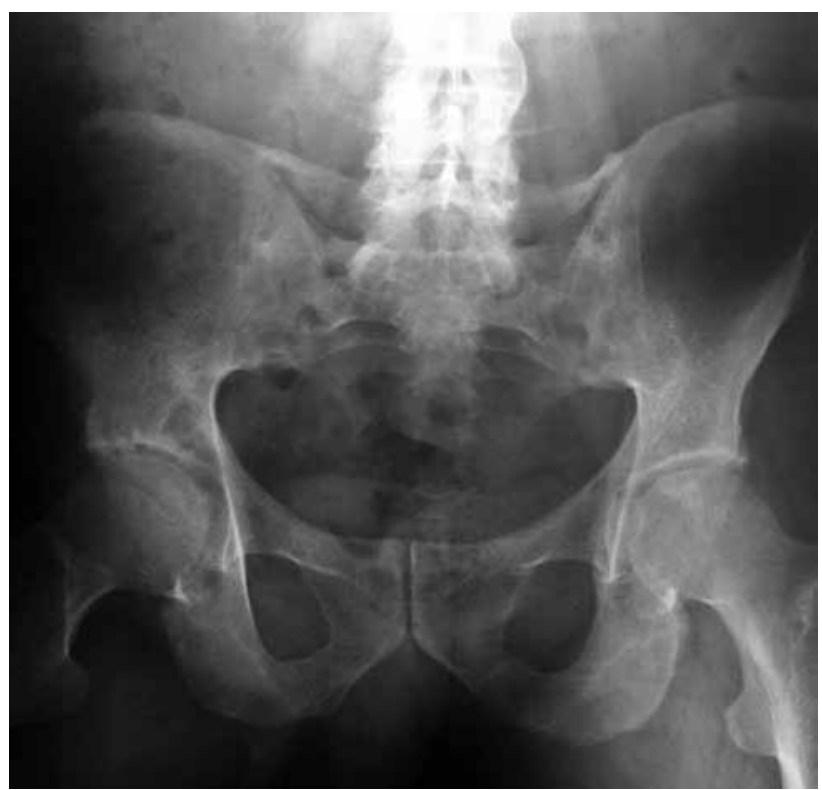

Figure 1. Anterior-posterior sacroiliac joint graph. the time of the attack, the laboratory findings were as follows: Erythrocyte sedimentation rate (ESR): $74 \mathrm{~mm} / \mathrm{h}, \mathrm{C}$-reactive protein (CRP): $(++++)$, fibrinogen: $721.2 \mathrm{mg} / \mathrm{dl}(180-360 \mathrm{mg} / \mathrm{dl})$, serum creatine: $1.6 \mathrm{mg} / \mathrm{dl}(0.5-1.2 \mathrm{mg} / \mathrm{dl})$, blood urea nitrogen: $66 \mathrm{mg} / \mathrm{dl}(10-50 \mathrm{mg} / \mathrm{dl})$, creatine clearance: $42 \mathrm{ml} / \mathrm{min}(71-151 \mathrm{ml} / \mathrm{min})$, and microprotein in 24-hour urine: $333 \mathrm{mg} /$ day ( $<150 \mathrm{mg} /$ day). The patient had combined heterozygote M680I and M694V mutations of the MEFV gene which is common in FMF. There was no finding of hepatosplenomegaly on the abdominal ultrasonography. The gingival biopsy was negative for amiloidosis. The patient's daughter, who had similar attacks, was also diagnosed with FMF eight months after him. The patient was started on colchicine treatment $(1.5 \mathrm{mg} /$ day $)$, and in the follow-up, he had attacks of abdominal pain and fever. His joint-related complaints regressed but did not completely resolve. The patient had been on leflunomid for 1.5 years and sulfasalazin for six months with no benefits and suffered from chronic renal failure. Thus, a TNF- $\alpha$ inhibitor (Adalimumab, $40 \mathrm{mg}$ every other week) was added to the treatment regimen with colchicine after two months. After the

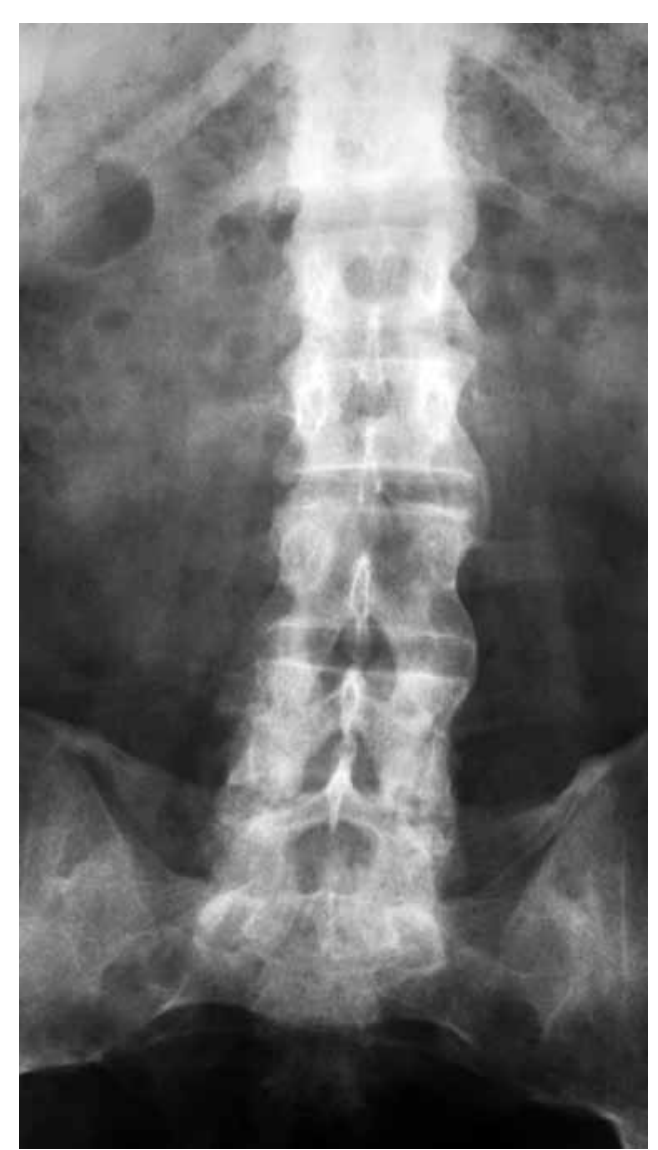

Figure 2. Anterior-posterior lumbosacral graph. 


\begin{tabular}{|c|c|c|c|}
\hline & Before the treatment & $\begin{array}{l}\text { In the } 3^{\text {rd }} \text { month } \\
\text { of the treatment }\end{array}$ & $\begin{array}{c}\text { After dropping ou } \\
\text { of the treatment }\end{array}$ \\
\hline Bath ankylosing spondylitis disease activity index & 5.2 & 1.2 & 3.1 \\
\hline Erythrocyte sedimentation rate $(\mathrm{mm} / \mathrm{sa})$ & 34 & 10 & 26 \\
\hline C-reactive protein $(\mathrm{mg} / \mathrm{l})$ & 17.2 & 9.33 & 13 \\
\hline Hemoglobin (g/dl) & 11.1 & 11.7 & 11.6 \\
\hline Platelets & 254.000 & 216.000 & 222.000 \\
\hline Blood urea nitrogen $(\mathrm{mg} / \mathrm{dl})$ & 91 & 69 & 54 \\
\hline Creatine (mg/dl) & 1.9 & 1.7 & 1.8 \\
\hline Microprotein in 24-hour urine (mg/day) & 333 & 254 & 188 \\
\hline
\end{tabular}

patient used this combination for nearly one year, his complaints significantly improved. The patient had only one attack in that period. However, the patient's adherence to therapy was poor, and he did not use the TNF- $\alpha$ inhibitor for four months. He reapplied to our clinic with the complaint of increased joint pain. $\mathrm{He}$ reported one abdominal pain attack during these four months. The Bath Ankylosing Spondylitis Disease Activity Index (BASDAI) and laboratory findings of the patient before, during, and after dropping out of the treatment have been presented in Table 1. After the controls, the patient was restarted on TNF- $\alpha$ inhibitor (Adalimumab) treatment.

\section{DISCUSSION}

Familial Mediterranean fever is a disease usually seen among people with Mediterranean origin and is characterized with self-limited attacks of fever and polyserositis. ${ }^{[2]}$ Articular involvement is the second most common presentation following abdominal pain. ${ }^{[13]}$ One of the musculoskeletal involvement forms of FMF is spondyloarthropathy, and, almost always, HLA-B27 is negative. In these patients, generally minimal radiological spinal involvement is accompanied with unilateral or bilateral sacroiliitis, recurrent entesitis, and inflammatory low back and neck pain. ${ }^{[5]}$ It has also been reported that AS may accompany FMF. ${ }^{[5,8,14]}$ In our patient, a positiveSchober's test, limited chest expansion, and the presence of bilateral stage IV sacroiliitis on the anterior-posterior sacroiliac joint graph with syndesmophytes on the anterior-posterior lumbosacral graph suggested FMF accompanied by AS.

In the treatment of FMF, colchicine is commonly used because of its potent inhibitory effect on neutrophile chemotaxis. ${ }^{[15]}$ Nearly one-fourth of FMF patients are partially or completely resistant to colchicine. ${ }^{[16]}$ Tumor necrosis factor alpha inhibitors have been reported to be effective in the treatment of FMF in many case reports. ${ }^{[4,9-12]}$ Most of the patients were treated with infliximab, and one patient was treated with etanercept. ${ }^{[9]}$ Our patient responded to TNF- $\alpha$ (adalimumab) treatment. After adalimumab was added to his treatment regimen with colchicine, a marked decrease was observed in FMF attacks, and AS disease activity improved.

Amyloid A (AA) amyloidosis which is a fatal complication of FMF can affect the kidneys and cause renal failure. It was reported that the proinflammatory cytokine TNF- $\alpha$ could be involved in the pathogenesis of secondary amyloidosis. ${ }^{[17]}$ The treatment with infliximab was demonstrated to be effective in the resolution of proteinuria resulting from renal amyloidosis in a patient with rheumatoid arthritis. ${ }^{[18]}$ Metyas et al. ${ }^{[19]}$ reported a case with renal amyloidosis secondary to FMF who was successfully treated with anti-TNF therapy. In the present case, there was not a significant improvement in renal functions and resolution of proteinuria with antiTNF therapy. The fact that the renal insufficiency was related with nephrolithiasis, a reason other than amyloidosis might explain the ineffectiveness of the therapy on renal functions in this patient.

The most prominent characteristic of FMF is the inflammatory reaction that affects the tissues such as the pleura, peritoneum, and synovium. The cloning of the MEFV/FMF gene and identification of mutations responsible for FMF have enabled a timely and definite diagnosis. It was found that the gene coded a protein produced by certain neutrophils known as 'pyrin' or 'marenostrin', and this protein has been shown to inhibit the inflammation. ${ }^{[20]}$ Thereby, any mutation of the MEFV gene leads to the synthesis of abnormal pyrin protein, and inflammation is not efficiently 
inhibited. ${ }^{[21]}$ The role of TNF- $\alpha$ in FMF has not been clearly established yet. There is no definitive evidence on TNF levels of FMF patients during acute attacks or in remission periods. Various studies have reported different results. ${ }^{[22-25]}$ The inability to demonstrate an increase in TNF levels (upregulation) during attacks consistently and repeatedly might have been due to differences in the methodologies used and the short-life of the cytokine. ${ }^{[23,24]}$ However, the in vitro stimulation of monocytes by TNF- $\alpha$ has been shown to cause MEFV expression. ${ }^{[20]}$ Our patient and previous data support a potential role of TNF in FMF pathogenesis. In FMF patients who do not respond to colchicine, TNF- $\alpha$ inhibitors may be considered a treatment option.

\section{Declaration of conflicting interests}

The authors declared no conflicts of interest with respect to the authorship and/or publication of this article.

\section{Funding}

The authors received no financial support for the research and/or authorship of this article.

\section{REFERENCES}

1. Ozen S. New interest in an old disease: familial Mediterranean fever. Clin Exp Rheumatol 1999;17:745-9.

2. Nir-Paz R, Ben-Chetrit E, Pikarsky E, Hassin D, Hasin Y, Chajek-Shaul T. Unusual presentation of familial Mediterranean fever: role of genetic diagnosis. Ann Rheum Dis 2000;59:836-8.

3. Majeed HA, Al-Qudah AK, Qubain H, Shahin HM. The clinical patterns of myalgia in children with familial Mediterranean fever. Semin Arthritis Rheum 2000;30:138-43.

4. Ozgocmen S, Ozçakar L, Ardicoglu O, Kocakoc E, Kaya A, Kiris A. Familial Mediterranean fever responds well to infliximab: single case experience. Clin Rheumatol 2006;25:83-7.

5. Langevitz P, Livneh A, Zemer D, Shemer J, Pras M. Seronegative spondyloarthropathyinfamilialMediterranean fever. Semin Arthritis Rheum 1997;27:67-72.

6. Altındağ Ö, Karakoç M, Soran N. Ankylosing spondylitis together with familial mediterranean fever: a concomitant disease or a feature of FMF? Rheumatism 2007;22:110-3.

7. BahadırC,OcakF, ÖnalB, ÖztürkB, KorkmazÖ,ÖnderCB. Familial Mediterranean fever complicated by avasculer necrosis of the femoral head, spondiloarthropathy and osteoporosis: case report Rheumatism 2007;22:36-9.

8. Knockaert DC, Malysse IG, Peetermans WE. Ankylosing spondylitis. An unusual manifestation of familial Mediterranean fever. Report of a case complicated by amyloidosis and polyneuropathy. Clin Rheumatol 1989;8:408-12.
9. Mor A, Pillinger MH, Kishimoto M, Abeles AM, Livneh A. Familial Mediterranean fever successfully treated with etanercept. J Clin Rheumatol 2007;13:38-40.

10. Nakamura A, Matsuda M, Tazawa K, Shimojima Y, Ikeda S. Successful treatment with infliximab and lowdose methotrexate in a Japanese patient with familial Mediterranean fever. Intern Med 2007;46:1247-9.

11. Aldea A, Campistol JM, Arostegui JI, Rius J, Maso M, Vives $\mathrm{J}$, et al. A severe autosomal-dominant periodic inflammatory disorder with renal AA amyloidosis and colchicine resistance associated to the MEFV H478Y variant in a Spanish kindred: an unusual familial Mediterranean fever phenotype or another MEFVassociated periodic inflammatory disorder? Am J Med Genet A 2004;124A:67-73.

12. Daysal S, Akcil G, Goker B, Haznedaroglu S, Ercan N, Ozturk MA. Infliximab therapy in a patient with familial Mediterranean fever and chronic hip arthritis. Arthritis Rheum 2005;53:146-7.

13. Özdolap S, Sarıkaya S, Aktunç E. Familial Mediterranean fever associated with ankylosing spondylitis: a case report. Rheumatism 2006;21:31-3.

14. Kaushik P, el-Sobkie NI, Shehab D, Malaviya AN. Familial Mediterranean fever with HLA B-27 positive ankylosing spondylitis in a young Armenian man. Clin Exp Rheumatol 1999;17:387-8.

15. Ben-Chetrit E, Levy M. Familial Mediterranean fever. Lancet 1998;351:659-64.

16. Lidar M, Scherrmann JM, Shinar Y, Chetrit A, Niel E, Gershoni-Baruch R, et al. Colchicine nonresponsiveness in familial Mediterranean fever: clinical, genetic, pharmacokinetic, and socioeconomic characterization. Semin Arthritis Rheum 2004;33:273-82.

17. Rysavá R, Merta M, Tesar V, Jirsa M, Zima T. Can serum amyloid A or macrophage colony stimulating factor serve as marker of amyloid formation process? Biochem Mol Biol Int 1999;47:845-50.

18. Elkayam O, Hawkins PN, Lachmann H, Yaron M, Caspi D. Rapid and complete resolution of proteinuria due to renal amyloidosis in a patient with rheumatoid arthritis treated with infliximab. Arthritis Rheum 2002;46:2571-3.

19. Metyas S, Arkfeld DG, Forrester DM, Ehresmann GR. Infliximab treatment of Familial Mediterranean fever and its effect on secondary AA amyloidosis. J Clin Rheumatol 2004;10:134-7.

20. Centola M, Wood G, Frucht DM, Galon J, Aringer M, Farrell C, et al. The gene for familial Mediterranean fever, $\mathrm{MEFV}$, is expressed in early leukocyte development and is regulated in response to inflammatory mediators. Blood 2000;95:3223-31.

21. Kastner DL. Familial Mediterranean fever: the genetics of inflammation. Hosp Pract (Minneap) 1998;33:131-4.

22. Baykal Y, Saglam K, Yilmaz MI, Taslipinar A, Akinci SB, Inal A. Serum sIL-2r, IL-6, IL-10 and TNF-alpha level in familial Mediterranean fever patients. Clin Rheumatol 2003;22:99-101. 
23. Schattner A, Lachmi M, Livneh A, Pras M, Hahn T. Tumor necrosis factor in familial Mediterranean fever. Am J Med 1991;90:434-8.

24. Gang N, Drenth JP, Langevitz P, Zemer D, Brezniak N, Pras M, et al. Activation of the cytokine network in familial
Mediterranean fever. J Rheumatol 1999;26:890-7.

25. Kiraz S, Ertenli I, Arici M, Calgüneri $M$, Haznedaroglu I, Celik I, et al. Effects of colchicine on inflammatory cytokines and selectins in familial Mediterranean fever. Clin Exp Rheumatol 1998;16:721-4. 